\title{
REGULATION OF SEMINIFEROUS TUBULAR FUNCTION BY FSH AND ANDROGEN
}

\author{
V. HANSSON,* S. G. WEDDINGTON, W. S. MaLEAN, A. A. SMITH, \\ S. N. NAYFEH, F. S. FRENCH AND E. M. RITZENं
}

Departments of Pediatrics and Biochemistry and The Laboratories for Reproductive Biology, University of North Carolina School of Medicine Chapel Hill, North Carolina 27514, U.S.A., and $\uparrow$ Department of Pediatrics, Karolinska Institutet, Stockholm, Sweden

\begin{abstract}
Summary. Seminiferous tubules contain a cytoplasmic androgen receptor similar to the receptors in the epididymis and ventral prostate. The presence of a cytoplasmic receptor indicates that androgens maintain spermatogenesis by a direct action on certain types of cells within the seminiferous tubule. The Sertoli cell appears to be one of the cell types containing androgen receptors and the receptor might also be present in spermatogonia, primary spermatocytes, or peritubular cells. The Sertoli cell is stimulated by FSH to produce an androgen-binding protein which may serve to increase the accumulation of androgen in the seminiferous epithelium and make it available for binding by intracellular androgen receptors. This may be a way in which FSH enhances the action of androgen on spermatogenesis. Androgens act on the Sertoli cell to increase its response to FSH. This action of androgens on the Sertoli cell results in increased production of androgen-binding protein and may enhance the production of other substances which exert trophic effects on spermatogenesis.
\end{abstract}

The synergistic effects of LH and FSH (Woods \& Simpson, 1961; Lostroh, 1963; Courot, 1970; Petrusz et al., 1970) and of androgens and FSH (Woods \& Simpson, 1961; Kalra \& Prasad, 1967) in initiating and maintaining spermatogenesis in hypophysectomized animals have been well demonstrated. While LH or androgens alone are also capable of maintaining spermatogenesis if the treatment is begun immediately after hypophysectomy, the minimum dose required is less than when either one of these hormones is given together with FSH (Woods \& Simpson, 1961; Kalra \& Prasad, 1967). Androgens, LH or FSH are each incapable of initiating spermatogenesis if regression of the germinal epithelium has been allowed to occur following hypophysectomy, but when FSH is given with LH or with androgens, the combinations are highly effective.

Recent studies from our own and other laboratories have provided a molecular

* Present address: Institute of Pathology, Rikshospitalet, Oslo 1, Norway. 
basis for the relative roles of androgens and $\mathrm{FSH}$ and for their synergistic actions in stimulating spermatogenesis. These are summarized as follows. (1) Seminiferous tubules contain intracellular receptors for androgens similar to the receptors in accepted androgen target organs (Hansson et al., 1973c, 1974b; McLean et al., 1974; Smith et al., 1975), indicating that the tubules also contain androgen-responsive target cells. (2) FSH has been shown to stimulate the production of an androgen-binding protein (ABP) (Ritzén et al., 1972a; Vernon et al., 1972, 1973, 1974; French \& Ritzén, 1973; Hansson et al., 1973d, 1974c), which is probably secreted by the Sertoli cells (Hagenäs et al., 1974; Vernon et al., 1974). It has been suggested that the stimulation of ABP production might serve as a regulatory mechanism whereby FSH acts synergistically with androgens to bring about an increase in the transport of androgens from the interstitial compartment into the seminiferous tubules (Hansson et al., 1974c). (3) Androgens augment FSH stimulation of Sertoli cell function as indicated by ABP production (Hansson et al., 1974a, d), and in high doses androgens alone appear capable of maintaining Sertoli cell function (Hansson et al., 1974d).

\section{ANDROGEN RECEPTORS}

Androgen-dependent tissues such as the epididymis and ventral prostate have been shown to contain receptor proteins for $\mathrm{C}_{19}$-steroids (Bruchovsky \& Wilson, 1968; Unhjem \& Tveter, 1969; Fang et al., 1969; Mainwaring, 1969; Blaquier, 1971; Tindall et al., 1972, 1974; Hansson et al., 1973b). Binding to the receptor is believed to be an essential initial step in androgen action on the target cell. It has now been shown that seminiferous tubules from the rat testis contain a receptor protein similar to the androgen receptors in other target tissues (Hansson et al., 1973c, 1974b; McLean et al., 1974; Smith et al., 1975).

The receptor was first identified in immature rats which had been hypophysectomized to reduce the level of endogenous androgens in the testis and then injected with $\left[{ }^{3} \mathrm{H}\right]$ testosterone of high specific activity. Supernatants $(105,000 \mathrm{~g})$ were prepared from homogenates of seminiferous tubules as well as from the epididymis and prostate, and binding was analysed by electrophoresis in $3.5 \%$ acrylamide gel containing $0.5 \%$ agarose. Gels were sliced into $2-\mathrm{mm}$ segments and the radioactivity measured in each slice by liquid scintillation counting. The cytoplasmic receptor in testis formed a slow moving peak with an electrophoretic mobility similar to the receptors in the epididymis and ventral prostate (Text-fig. 1). Binding to the receptor was inhibited completely by the simultaneous injection of unlabelled testosterone, dihydrotestosterone, or cyproterone, indicating a low binding capacity which is characteristic of intracellular receptors for steroid hormones. In subsequent studies, the testicular androgen receptor has been shown to have other characteristics similar to those of the other target organs (Table 1). It sediments as a $4 \mathrm{~S}$ component in 0.4 $\mathrm{M}-\mathrm{KCl}$ and as a 7-10S component at low salt concentrations (Hansson et al., 1973c, 1974b; McLean et al., 1974). The receptors have Stokes' radii greater than $80 \AA$ and molecular weights greater than 200,000 , as determined by gel filtration on Sephadex G-200 and sucrose-gradient centrifugation (McLean et al., 1975; Hansson et al., 1974b). Their relative mobility ( $R f$ relative to 


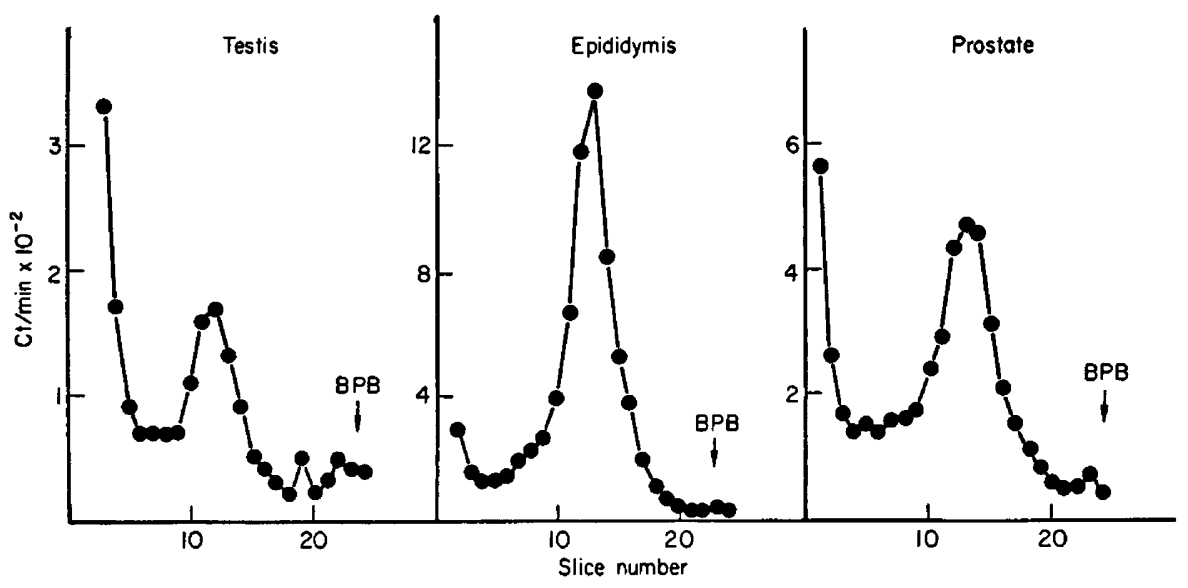

Text-Fic. 1. Polyacrylamide gel electrophoresis of $105,000 \mathrm{~g}$ supernatants of testis, epididymis and prostate. Sprague-Dawley rats were hypophysectomized at 25 days of age. Eight days later, the anaesthetized rats were functionally hepatectomized, eviscerated and injected i.v. with $\left[1,2,6,7-{ }^{3} \mathrm{H}\right]$ testosterone $(50 \mu \mathrm{Ci})$. The animals were killed $3 \mathrm{hr}$ later and the tissues homogenized in 3 vol $50 \mathrm{~mm}$-tris-HCl (pH 7.4) containing $0.32 \mathrm{M-}$ sucrose and $3 \mathrm{mM}-\mathrm{MgCl}_{2}$ and centrifuged at $105,000 \mathrm{~g}$ for $1 \mathrm{hr}$. Aliquots of supernatants were analysed by polyacrylamide gel electrophoresis on $3.5 \%$ acrylamide gels containing $0.5 \%$ agarose as described previously (Hansson et al., 1974b). (Data from McLean et al., 1975.)

bromphenol blue) by polyacrylamide gel electrophoresis is 0.4 to 0.5 (Hansson et al., 1973c). A characteristic feature of androgen-receptor complexes is their slow rate of dissociation at $0^{\circ} \mathrm{C}$. Androgen-receptor complexes in testis dissociate at a rate similar to those in epididymis and prostate (McLean et al., 1975). In these studies, the receptor complexes were labelled by injection of tritiated testosterone and were allowed to stand at $0^{\circ} \mathrm{C}$ for various periods of time in the presence of an excess of unlabelled testosterone to prevent reassociation of labelled androgen after it had dissociated from the receptor. Binding was analysed by gel electrophoresis. Labelled androgen-receptor complexes in testis, epididymis and prostate dissociated over a period of days. Further similarities

Table 1. Comparison of known characteristics of cytoplasmic receptors of the prostate, testis and epididymis with those of $A B P$

\begin{tabular}{|c|c|c|c|c|}
\hline & \multicolumn{3}{|c|}{ Cytoplasmic receptors } & \multirow{2}{*}{$A B P$} \\
\hline & Testis & Epididymis & Prostate & \\
\hline $\begin{array}{l}\text { Sedimentation coefficient } \\
\text { Stokes' radius } \\
\text { Molecular weight } \\
\text { PAGE ( } 31 \% \% \text { gels) } \\
\text { Dissociation rate of bound androgen } \\
\text { Heating at } 50^{\circ} \mathrm{C}, 30 \mathrm{~min} \\
\text { Sulphhydryl agent PCM PS ( } 1 \mathrm{mM}) \\
\text { Charcoal } \\
\text { Protease }\end{array}$ & $\bar{z}$ & $\begin{array}{l}4 \mathrm{~S} \text { and } 7-10 \mathrm{~S} \\
>80 \AA \\
>200,000 \\
\text { Rf } 0 \cdot 4-0 \cdot 5 \\
\text { t } \frac{1}{2} 0^{\circ}>2 \text { days } \\
= \\
=\end{array}$ & $\bar{z}$ & $\begin{array}{l}4 \cdot 6 \mathrm{~S} \\
47 \AA \\
\sim 87,000 \\
\operatorname{Rf} 0 \cdot 75 \\
\text { to } 0^{\circ}-6 \mathrm{~min} \\
+ \\
+ \\
+ \\
+\end{array}$ \\
\hline
\end{tabular}

$(-)$ indicates binding destroyed; $(+)$ indicates binding intact. 
in the receptors were found in their sensitivity to destruction by the sulphhydryl agent (parachloromercuriphenylsulphonate), prolonged exposure to dry charcoal, or by exposure to heat at $50^{\circ} \mathrm{C}$ for 30 min (McLean et al., 1975; Hansson et al., 1973b; Tindall et al., 1974).

The androgen receptor in the testis appears to have a different binding specificity from receptors in the epididymis in that relatively more testosterone than dihydrotestosterone is bound after injection of $\left[{ }^{3} \mathrm{H}\right]$ testosterone in vivo or incubation with equimolar amounts of $\left[{ }^{3} \mathrm{H}\right]$ testosterone and $\left[{ }^{3} \mathrm{H}\right] 5 \alpha-$ dihydrotestosterone in vitro. This apparent difference may result, however, from rapid conversion (even at $0^{\circ} \mathrm{C}$ ) of $5 \alpha$-dihydrotestosterone to $5 \alpha$-androstane- $3 \alpha$, $17 \beta$-diol which is not readily bound by the receptor (McLean et al., 1975).

Translocation of cytoplasmic androgen-receptor complexes into nuclei of seminiferous tubules was suggested by the demonstration of a nuclear androgenbinding protein with steroid specificity identical to the cytoplasmic receptor. Labelled androgen-protein complexes could be extracted from purified nuclei with 0.4 to $1.0 \mathrm{M}-\mathrm{KCl}$ and had a sedimentation coefficient of $3-4 \mathrm{~S}$. Following the injection of $\left[{ }^{3} \mathrm{H}\right]$ testosterone in vivo, the relative amounts of $\left[{ }^{3} \mathrm{H}\right]$ testosterone and $\left[{ }^{3} \mathbf{H}\right]$ dihydrotestosterone bound to the nuclear receptor were similar to the amounts bound to the cytoplasmic receptor (Smith et al., 1975).

Further evidence that this seminiferous tubular protein is an intracellular receptor has been obtained from studies on androgen-insensitive rats. These animals have been shown to have a congenital defect in the response of target cells to androgen which is associated with a lack of nuclear uptake of androgen (Ritzén et al., 1972b; Bardin et al., 1973) and an absence of androgen receptors in preputial gland (Bardin et al., 1973) and kidney (W. S. McLean, A. A. Smith, V. Hansson, S. N. Nayfeh \& F. S. French, unpublished data). For this reason, we examined androgen binding in supernatants of testicular homogenates of androgen-insensitive rats and normal male siblings. If this binding protein were in fact a receptor, it would not be present in the testes of the defective animals. A conspicuous absence of receptor binding in cytosol was demonstrated, whilst nuclear uptake of radioactivity was negligible and again no bound radioactivity could be extracted (McLean et al., 1974). The histological appearance of the seminiferous tubules in hypophysectomized immature androgeninsensitive rats closely resembled that in the hypophysectomized normal male. The epithelium was two cell layers in thickness and contained only Sertoli cells, spermatogonia and few primary spermatocytes. The histological similarity of the epithelium in the immature androgen-insensitive rats and their normal littermates confirmed that absence of response to androgen results from lack of androgen receptors in the target cell rather than lack of the target cell itself.

Studies carried out in immature hypophysectomized rats have shown that the androgen receptor increases per unit weight of testis after the seminiferous epithelium has undergone full regression, i.e. up to 1 month after hypophysectomy (Hansson et al., 1974b). Under these conditions, the epithelium contains only Sertoli cells, spermatogonia, and primary spermatocytes, indicating that the receptor is in one or more of these cell types and perhaps in peritubular cells as well. It has not been possible to demonstrate an androgen receptor in interstitial cells (McLean et al., 1974; Hansson et al., 1974b). 
To determine whether Sertoli cells might contain a receptor, germ cells were destroyed by exposing pregnant rats to 150 rads from a cobalt-60 source on Day 19 of gestation when the germ cells are known to be highly radiosensitive (Beaumont, 1960; Means \& Huckins, 1974), and the testes then contained tubules with Sertoli cells only (Hagenäs et al., 1974, 1975). Binding in the supernatants of testicular homogenates from hypophysectomized Sertoli cell-only rats was compared with that in non-irradiated rats hypophysectomized at the same age. Gel electrophoresis of testis supernatants labelled in vivo with $\left[{ }^{3} \mathrm{H}\right]$ testosterone showed that the concentration of receptor was undiminished. These preliminary studies suggest that if the receptor is present in the seminiferous epithelium, then it must be present in Sertoli cells. The studies do not exclude the possibility that androgen receptors are present in germ cells and peritubular cells as well (McLean et al., 1974).

\section{ANDROGEN-BINDING PROTEIN}

It appears likely that the seminiferous tubules contain high concentrations of androgen relative to other target tissues, since the concentration of testosterone in testicular efferent duct fluid is similar to that in spermatic venous blood which is 10 times higher than in peripheral blood (French \& Ritzén, 1973; Harris \& Bartke, 1974). Testosterone produced in the interstitial compartment should be able to enter the venous effluent and lymphatic drainage of the testis quite easily but might meet a relative barrier to diffusion into the seminiferous tubules. It seemed reasonable to assume that some mechanism might exist to promote the accumulation of androgen in the seminiferous tubules. We have postulated that the androgen-binding protein $(\mathrm{ABP})$ plays a role in this process.

We initially observed the presence of ABP in 105,000 g supernatants of epididymis labelled in vitro by equilibration with $\left[{ }^{3} \mathrm{H}\right]$ dihydrotestosterone and fractionated by polyacrylamide gel electrophoresis (Ritzén et al., 1973; Hansson et al., 1973a). A peak of bound radioactivity was found in the epididymis, but little or no binding was observed in the testis until the large amount of endogenous androgen was first removed by treatment with charcoal (Ritzén et al., 1973). Testis supernatant was then shown to contain a binding component identical to $\mathrm{ABP}$ in the epididymis. That the binding protein normally passes from testis to epididymis was demonstrated by showing its accumulation in the testis and depletion in the epididymis following ligation of the efferent ducts. This finding also indicated that $\mathrm{ABP}$ is secreted in testicular fluid which was confirmed after collecting fluid from the rete testis. Analysis by gel electrophoresis showed a single peak of bound radioactivity with an electrophoretic mobility identical to the ABP in testis and epididymis (French \& Ritzén, 1973; Ritzén et al., 1974a). Binding in efferent duct fluid was measured by gel electrophoresis after saturation of the fluid with labelled steroids and by Sephadex gel equilibration. Dihydrotestosterone was demonstrated to have a higher affinity than testosterone by both methods (Text-fig. 2). The concentration of $\mathrm{ABP}$ in efferent duct fluid, as determined from the $\mathrm{x}$-intercept of the Scatchard plot, approached $100 \mathrm{nmol}$, which similar to that of testosterone in efferent duct fluid (French \& Ritzén, 1973). 


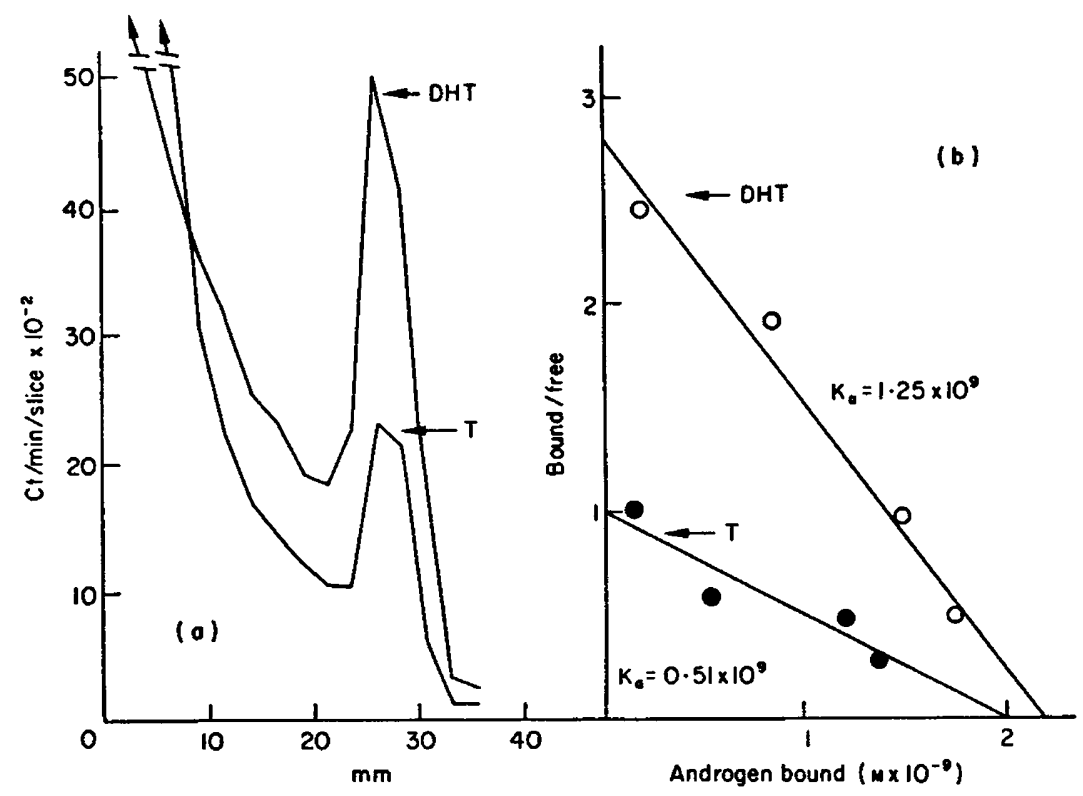

Text-FIG. 2. (a) Binding of $\left[1,2,-{ }^{3} \mathrm{H}\right]$ dihydrotestosterone (DHT) and $\left[1,2-{ }^{3} \mathrm{H}\right]$ testosterone $(T)$ in rat efferent duct fluid analysed by electrophoresis on $6.5 \%$ polyacrylamide gels after equilibration with saturating amounts of labelled steroids. (b) Scatchard plots of binding in efferent duct fluid as measured by Sephadex gel equilibration. (Data from French \& Ritzén, 1973.)

In contrast to the cytoplasmic receptors, $\mathrm{ABP}$ is a smaller molecule with a sedimentation coefficient of $4.6 \mathrm{~S}$ at low salt concentrations (Hansson et al., 1973a), a Stokes' radius of $47 \AA$, and a molecular weight of about 87,000 . The complexes of $\mathrm{ABP}$ with $\left[{ }^{3} \mathrm{H}\right]$ dihydrotestosterone dissociate extremely rapidly at $0^{\circ} \mathrm{G}\left(\mathrm{t} \frac{1}{2}=6 \mathrm{~min}\right)$, but are unaffected by heating at $50^{\circ} \mathrm{C}$ or by exposure to parachloromercuriphenylsulphonate or dry charcoal (Table 1).

Vernon et al. (1974) measured high-affinity binding activity in seminiferous tubules and were unable to find similar binding activity in interstitial tissue. Although these studies did not distinguish between binding to the androgen receptor or $A B P$, they suggested that $A B P$ might be produced by the seminiferous epithelium. The possibility remained, however, that ABP might enter the tubular fluid by diffusion from the interstitial compartment, even though no binding activity could be measured in the interstitial cells. If ABP were produced in the interstitial compartment, it would almost certainly be present in the testicular lymph surrounding the tubules. This was shown not to be the case when lymph collected from the punctured testicular capsule was examined.

The site of production of ABP within the seminiferous tubules was determined by destroying the germ cells with irradiation or nitrofurazon and showing that the production of ABP was undiminished (Ritzén et al., 1974b), indicating that the Sertoli cell is the source. Fritz and his co-workers (Vernon et al., 1974) have obtained further evidence for Sertoli cell production of androgen-binding protein by the measurement of protein secretion in cultures of isolated Sertoli cells. It seems certain that the Sertoli cell is the site of production of ABP. 
The ABP has been shown to be regulated by pituitary gonadotrophins since its production is stimulated by them and it disappears following hypophysectomy (Vernon et al., 1973, 1974; Hansson et al., 1973d; Sanborn et al., 1974). In the immature rat hypophysectomized at 28 days of age, $\mathrm{ABP}$ decreases to almost undetectable levels within 3 days of the operation (Hansson et al., 1974c), while in the mature rat the decline is slower (Vernon et al., 1974; Sanborn et al., 1974). Within $24 \mathrm{hr}$ of an injection of FSH into immature hypophysectomized rats, there is an accumulation of $\mathrm{ABP}$ in the testis and epididymis, the levels in the latter reaching a plateau within 2 to 4 days. For this reason, the response was studied after treatment for 3 days. Hypophysectomized rats, four in each group, were injected with 30 to $500 \mu \mathrm{g}$ NIH-FSH-P1/day (Text-fig. 3). The log dose response was linear in the range of 60 to $250 \mu \mathrm{g} \mathrm{FSH} /$ day. The sensitivity of the FSH response was shown to be comparable to that of the ovarian weight augmentation assay of Steelman and Pohley (Hansson et al., 1975).

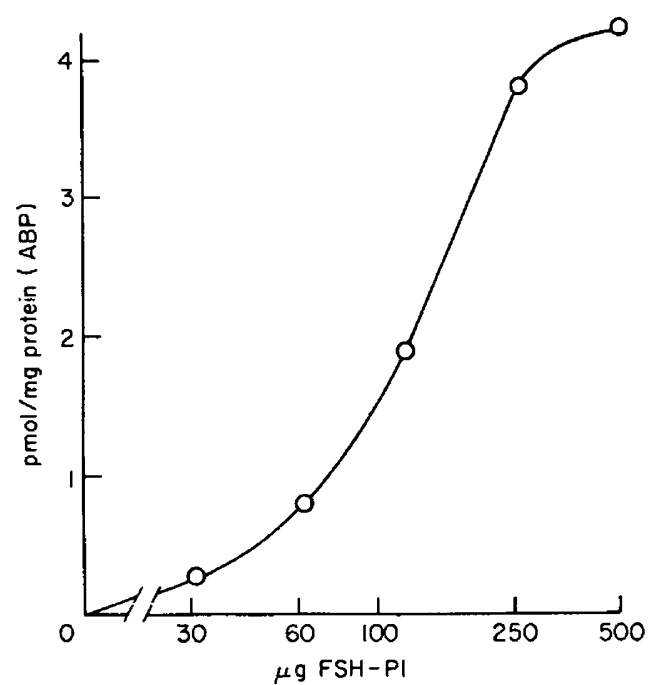

TEXT-FIG. 3. Concentrations of ABP in caput epididymidis after treatment for 3 days with NIH-FSH-P1. Rats were hypophysectomized at 28 days of age and 2 days later four rats/group were given injections of FSH twice daily. Epididymides from each group were pooled and the $105,000 \mathrm{~g}$ supernatants were analysed in duplicate using steadystate polyacrylamide gel electrophoresis (Ritzén et al., 1974a). (Data from Hansson et al., 1974d.)

The specificity of the FSH response was examined to determine if the ABP response to FSH could result from contamination of the FSH preparation with other pituitary hormones, androgens or oestrogens (Table 2). The results indicated that $\mathrm{ABP}$ was stimulated by FSH and not by a contaminant in the preparation.

The stimulation of ABP production by FSH suggests the Sertoli cell as the site of FSH action. Recent studies have shown that FSH stimulates the formation of cyclic AMP (cAMP) in isolated Sertoli cells (Dorrington et al., 1972; Dorrington \& Fritz, 1974), and Means and co-workers have shown specific binding of ${ }^{3} \mathrm{H}$-labelled FSH to membranes from seminiferous tubules containing 
Table 2. Specificity of the androgen-binding protein response

\begin{tabular}{|c|c|}
\hline Treatment & $\begin{array}{l}\text { Androgen-binding protein } \\
\left(\text { pmol/mg protein } \times 10^{2}\right)\end{array}$ \\
\hline $\begin{array}{l}\text { None (controls) } \\
\text { FSH (0.14 NIH-S1 unit)* } \\
\text { FSH (0.28 NIH-S1 unit)* } \\
\text { LH (NIH-LH-S17; } 0.06 \text { NIH-S1 unit)* } \ddagger \\
\text { TSH (0.06 USP unit)*ฐ } \\
\text { Bovine growth hormone }(0.3 \mathrm{NIH}-\mathrm{GH}-\mathrm{B} 16 \text { unit)*T } \\
\text { Ovine prolactin }(1.9 \text { i.u. })^{*} \neq \\
\text { Testosterone propionate }(2 \mathrm{mg}) \dagger \\
\text { Oestradiol-17 } \beta \text {-valerate }(500 \mu \mathrm{g}) \dagger\end{array}$ & $\begin{array}{l}\text { N.D. } \\
108 \\
286 \\
\text { N.D. } \\
\text { N.D. } \\
\text { N.D. } \\
\text { N.D. } \\
\text { N.D. } \\
\text { N.D. }\end{array}$ \\
\hline
\end{tabular}

Rats were hypophysectomized at 28 days of age and hormone treatment for groups of four was started 2 days later. The ABP was measured in caput epididymidis supernatant by steady state polyacrylamide gel electrophoresis. N.D. $=\mathrm{ABP}$ concentrations $<10 \mathrm{pmol} / \mathrm{mg}$ protein $\times 10^{2}$.

* Injected twice daily for 3 days to give the total dose indicated.

$\dagger$ A single dose on the first day.

$\neq$ This dose was $\times 20$ the maximum contamination in the dose of 0.28 unit FSH.

$\int$ This dose contained $\times 4$ the maximum contamination in the dose of $0 \cdot 28$ unit FSH.

If This dose was $\times 10$ the amount of growth hormone giving significant growth in a 5-day assay.

Sertoli cells only (see Means, 1973). The binding to membrane receptors has been shown to have a close temporal relationship to the accumulation of cAMP and the stimulation of protein kinase (Means \& Huckins, 1974). Production of $\mathrm{ABP}$ is also controlled by FSH in rat testes containing only Sertoli cells (Textfig. 4); ABP disappears from the epididymis after hypophysectomy and is increased by treatment with NIH-FSH-S10.

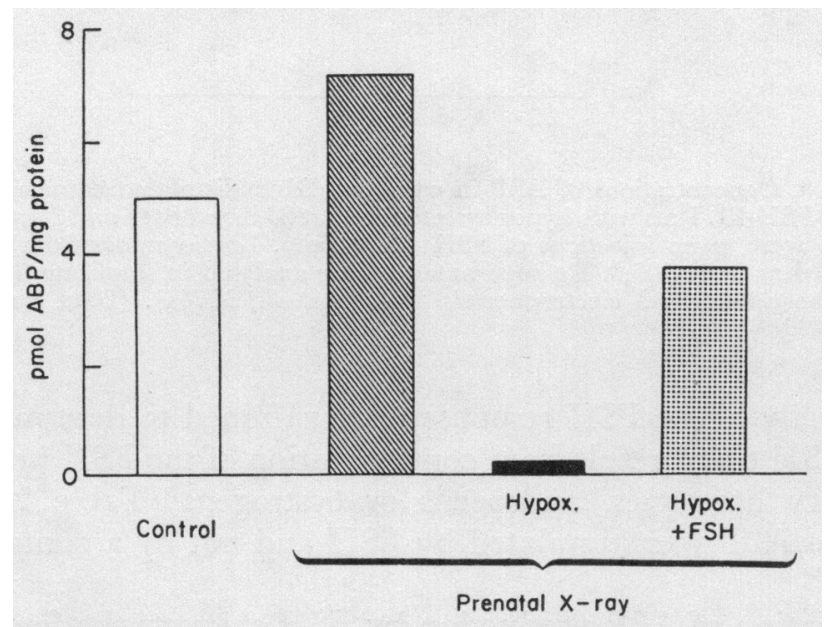

Text-kIG. 4. The stimulation by FSH of ABP production in rat testis containing only Sertoli cells. Germ cells were destroyed by exposing pregnant rats to 150 rads from a cobalt-60 source on Day 19 of gestation. Rats were hypophysectomized at 25 days of age and given $500 \mu \mathrm{g}$ NIH-FSH-S10/day subcutaneously for 3 days. The ABP in the epididymal supernatants was measured as shown in Text-fig. 3. (Data from Hagenäs et al., 1974b.) 
The finding that FSH stimulates ABP production by the Sertoli cell has led to the suggestion that FSH may thereby regulate a transport system which serves to increase the net uptake of testosterone and dihydrotestosterone by the seminiferous tubules. Binding by ABP may serve to protect these androgens from further metabolism so that they are available to receptor sites, either within the Sertoli cell itself or possibly in certain types of germ cells.

\section{ANDROGEN AUGMENTATION OF SERTOLI GELL RESPONSE TO FSH}

The $\mathrm{ABP}$ response to $\mathrm{FSH}$ was examined at various times after hypophysectomy and androgen treatment in order to determine whether androgens influence the Sertoli cell response to FSH. In Text-fig. 5, it is shown that the ABP response diminishes following hypophysectomy and can be restored by treatment with androgens. When hypophysectomized animals were treated with $2 \mathrm{mg}$ testosterone propionate daily, beginning 1 day after hypophysectomy, the dose response to FSH was maintained at a higher level than that seen 2 days after hypophysectomy without androgen treatment (Hansson et al., 1974a). This finding suggested that androgens play a role in maintaining Sertoli cell function and that their influence on FSH action might be as important as that of FSH on androgen action.

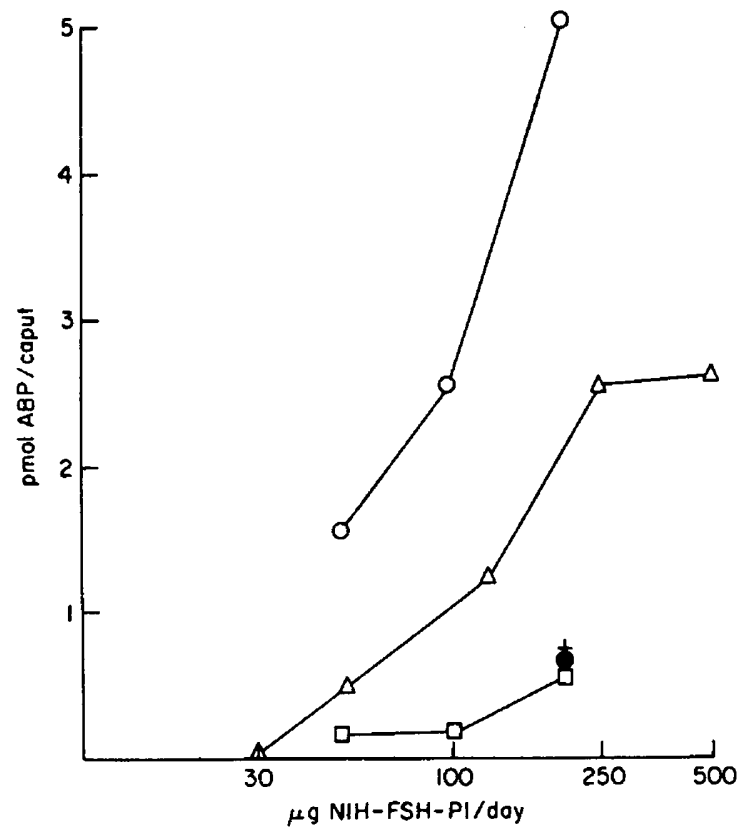

TeXT-FIG. 5. Diminished response to FSH after hypophysectomy and augmentation of $t$ he response by treatment with androgen. The accumulation of ABP was measured in the caput epididymidis in response to increasing doses of NIH-FSH-P1. Four groups of rats were hypophysectomized at 28 days of age and FSH treatment was started $2(\Delta)$, $7(\square), 20(+)$ or $33(\bigcirc)$ days later, twice daily for 3 days using four rats/group. Rats in one group (O) were given $2 \mathrm{mg}$ testosterone propionate daily starting 1 day after hypophysectomy. Supernatants were analysed by steady-state polyacrylamide gel electrophoresis as shown in Text-fig. 3. (Data from Hansson et al., 1974a.) 


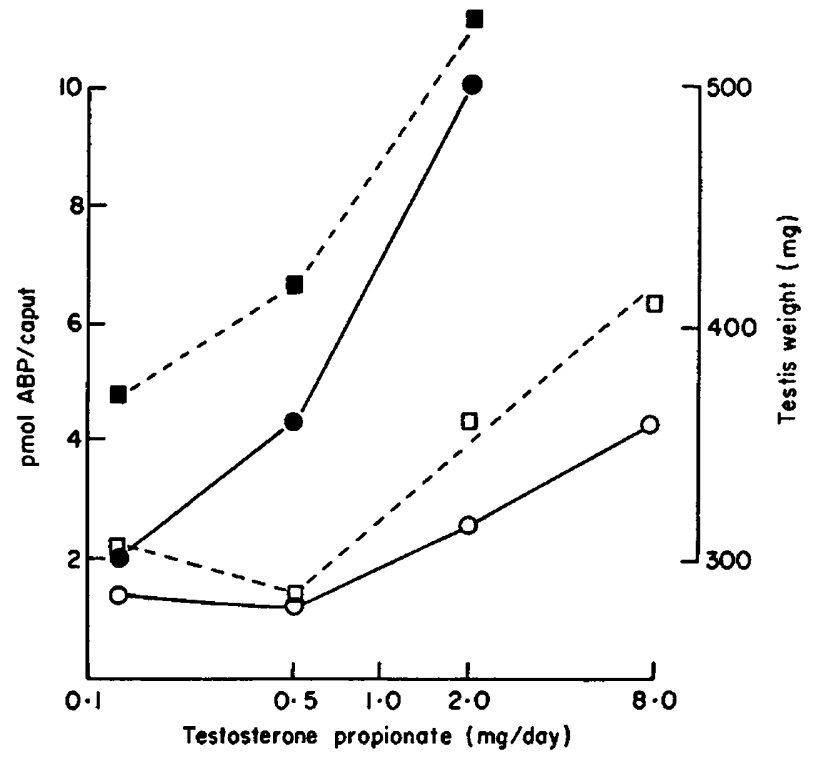

Texr-pig. 6. Effect of dose of testosterone propionate on testicular weight (squares) and the maintenance of ABP formation (circles), alone (open symbols) and with FSH (solid symbols). Rats were hypophysectomized at 28 days of age and groups of eight rats were given daily intramuscular injections of testosterone propionate for 9 days starting at 30 days of age. On the last 3 days of treatment (Days 7 to 9), four rats in each group were treated daily with NIH-FSH-S10 $100 \mu \mathrm{g}(0.11 \mathrm{NIH}$ unit). On Day 10, the epididymides from four rats were pooled, and ABP was measured by steady-state polyacrylamide gel electrophoresis.

To determine whether androgen augmentation of the FSH response might be dose-related, rats were treated with various doses of testosterone propionate for 10 days beginning 1 day after hypophysectomy. Surprisingly, androgen alone maintained $\mathrm{ABP}$ production and even caused some increase at very high

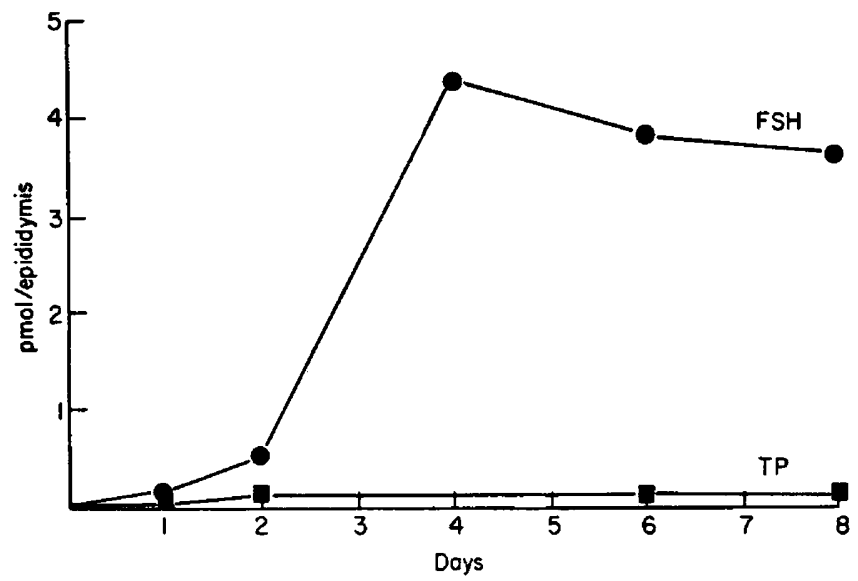

TexT-FIG. 7. The absence of ABP response to testosterone propionate was measured in the epididymis after regression of the immature rat testis following hypophysectomy. The ABP in epididymal $105,000 \mathrm{~g}$ supernatants was measured by steady-state polyacrylamide gel electrophoresis. 
dosages. Furthermore, when FSH was given daily for the final 3 days of treatment, the $\mathrm{ABP}$ response to $\mathrm{FSH}$ increased with increasing doses of androgen. In both instances, testis weight increased with the $\mathrm{ABP}$ response (Hansson et al., 1974d and Text-fig. 6). This finding that androgen alone is capable of maintaining $A B P$ production is reminiscent of the earlier observation that androgen is capable of maintaining spermatogenesis when given immediately following hypophysectomy. It suggests that when androgen treatment maintains spermatogenesis, it also maintains Sertoli cell function.

We next looked to see if androgen alone is capable of initiating Sertoli cell function when treatment following hypophysectomy is delayed until after the seminiferous tubular epithelium has been allowed to undergo some degree of regression. Rats were hypophysectomized at 28 days of age and 10 days later $4 \mathrm{mg}$ testosterone propionate/day were given for 8 days (Text-fig. 7). No ABP response was measurable in the epididymis, and only slightly increased levels of ABP were found in the testis. Under the same conditions, the Sertoli cells remained responsive to FSH. This finding that androgens alone are less effective in initiating than in maintaining Sertoli cell function may explain why they are less capable of initiating spermatogenesis under similar conditions. It reemphasizes the importance of the Sertoli cell in spermatogenesis (Kierszenbaum, 1974) and indicates that spermatogenesis requires functional Sertoli cells as well as androgens.

Sanborn et al. (1974) have measured the ABP response to testosterone in hypophysectomized sexually mature rats after regression of the germinal epithelium. Prolonged treatment with testosterone was associated with appreciable stimulation of ABP. This finding is not inconsistent with the above relationships, since it has been shown by Boccabella (1963) that some degree of spermatogenesis can be initiated in the fully regressed testis of the hypophysectomized rat after prolonged testosterone treatment. Furthermore, Vernon et al. (1973) showed that hypophysectomized mature rats respond to LH with an increase in high-affinity androgen-binding activity in testis supernatants.

\section{ACKNOWLEDGMENTS}

Financial support was given by National Institutes of Health, U.S.A. (research grant HDO4466 and training grant AMO5330), The Rockefeller Foundation, World Health Organization (grant H9/181/83), Swedish Medical Research Council (grant 3168), and the Norwegian Research Council for Sciences and the Humanities. One of us (V.H.) was a Fogarty International Fellow, University of North Carolina, 1973-1974.

\section{REFERENCES}

Bardin, G.W., Bullock, L.P., Sherins, R.J., Mowszowicz, I. \& Blackburn, W.R. (1973) Androgen metabolism and mechanism of action in male pseudohermaphroditism: a study of testicular feminization. Recent Prog. Horm. Res. 29, 65-109.

Beaumont, H.M. (1960) Changes in the radiosensitivity of the testis during foetal development. Int. F. rad. Biol. 2, 247-256.

BLAQUTER, J.A. (1971) Selective uptake and metabolism of androgens by rat epididymis. The presence of a cytoplasmic receptor. Biochem. biophys. Res. Commun. 45, 1076-1082. 
Bocabella, A.V. (1963) Reinitiation and restoration of spermatogenesis with testosterone propionate and other hormones after a long-term post-hypophysectomy regression period. Endocrinology 72, 787-798.

BRuchovsky, N. \& Wilson, J.D. (1968) The intranuclear binding of testosterone and $5 \alpha$-androstane$17 \beta$-ol-3-one by rat prostate. 7. biol. Chem. 243, 5953-5960.

Courot, M. (1970) Effect of gonadotrophins on the seminiferous tubules of the immature testis. In The Human Testis, p. 355. Eds. E. Rosenberg and C. A. Paulsen. Plenum Press, New York.

DoRrington, J.H. \& FRITZ, I.B. (1974) Effects of gonadotropins on cyclic AMP production by isolated seminiferous tubule and interstitial cell preparations. Endocrinology 94, 395-403.

Dorrington, J.H., Vernon, R.G. \& Frrtz, I.B. (1972) The effect of gonadotrophins on the $3^{\prime}, 5^{\prime}$-AMP levels of seminiferous tubules. Biochem. biophys. Res. Commun. 46, 1523-1528.

Fang, S., Anderson, K.M. \& Liao, S. (1969) Receptor proteins for androgens: on the role of specific proteins in selective retention of $17 \beta$-hydroxy-5 $\alpha$-androstan-3-one by rat ventral prostate in vivo and in vitro. 7 . biol. Chem. 244, 6584-6595.

French, F.S. \& Ritzén, E.M. (1973) Androgen-binding protein in efferent duct fluid of rat testis. F. Reprod. Fert. 32, 479-483.

Hagenäs, L., Ritzén, E.M., French, F.S. \& Hansson, V. (1974) Testicular androgen binding protein (ABP). Localization of site of production. 7. Steroid Biochem. 5, 382, Abstr.

Hagenäs, L., Ritzén, E.M., Plöen, L., Hansson, V., French, F.S. \& Nayfeh, S.N. (1975) Sertoli cell origin of testicular androgen binding protein (ABP). Molec. cell. Endocr. (in press).

Hansson, V., Djoseland, O., Reusch, E., Atrramadal, A. \& Torgersen, O. (1973a) An androgen binding protein in the testis cytosol fraction of adult rats. Comparison with the androgen binding protein in the epididymis. Steroids 21, 457-474.

Hansson, V., Djoseland, O., Reusch, E., Attramadal, A. \& Torgersen, O. (1973b) Intracellular receptors for $5 \alpha$-dihydrotestosterone in the epididymis of adult rats. Comparison with the androgenic receptors in the ventral prostate and the androgen-binding protein ( $\mathrm{ABP}$ ) in the testicular and epididymal fluid. Steroids 22, 19-33.

Hansson, V., Malean, W.S., Smith, A.A., Tindall, D.J., Nayfeh, S.N. \& French, F.S. (1973c) Androgen receptors in rat testis different from testicular androgen binding protein (ABP). Int. Res. Commun. Syst. 1, 27.

Hansson, V., Reusch, E., Ritzen, E.M., French, F.S., Trygstad, O. \& Torgersen, O. (1973d) FSH stimulation of testicular androgen binding protein. Nature, New Biol. 246, 56-58.

Hansson, V., French, F.S., Weddington, S.C., Nayfeh, S.N. \& Ritzén, E.M. (1974a) Androgen augmentation of FSH stimulation of ABP. In Hormone Binding and Activation in the Testis, pp. 28-31. Eds. M. Dufau and A. R. Means. Academic Press, New York.

Hansson, V., Mclean, W.S., Smith, A.A., Tindall, D.J., Weddington, S.C., Nayfeh, S.N., French, F.S. \& RITZÉN, E.M. (1974b) Androgen receptors in rat testis. Steroids 23, 823-832.

Hansson, V., Trygstad, O., French, F.S., Mclean, W.S., Smith, A.A., Tindall, D.J., Weddington, S.C., Petrusz, P., Nayfer, S.N. \& Ritzén, E.M. (1974c) Androgen transport and receptor mechanisms in rat testis and epididymis. Nature, Lond. 250, 387-391.

Hansson, V., Weddington, S.C., Ritzén, E.M., NAYFeh, S.N. \& French, F.S. (1974d) FSH stimulation of testicular androgen binding protein (ABP): augmentation of the FSH response by androgen. Endocrinology 94, A200.

Hansson, V., Weddington, S.C., Petrusz, P., Rrtzen, E.M., Nayfeh, S.N. \& French, F.S. (1975) FSH stimulation of testicular androgen binding protein. Endocrinology (in press).

Harris, M.E. \& Bartke, A. (1974) Concentration of testosterone in testis fluid of the rat. Endocrinology 95, 701-706.

Kalra, S.P. \& Prasad, M.R.N. (1967) Effect of FSH and testosterone propionate on spermatogenesis in immature rats treated with clomiphene. Endocrinology 81, 965-975.

Kierszenbaum, A.L. (1974) RNA synthetic activities of Sertoli cells in the mouse testis. Biol. Reprod. 10, 11, 365-376.

LostroH, A.J. (1963) Effect of follicle-stimulating hormone and interstitial cell-stimulating hormone on spermatogenesis in Long-Evans rats hypophysectomized for six months. Acta endocr., Copenh. 43, $592-600$.

Mainwaring, W.I.P. (1969) The binding of $\left[1,2-{ }^{3} \mathrm{H}\right]$ testosterone within nuclei of the rat prostate. 7. Endocr. 44, 323-333.

MeAns, A.R. (1973) Specific interaction of ${ }^{3} \mathrm{H}-\mathrm{FSH}$ with rat testis binding sites. In Receptors for Reproductive Hormones, pp. 431-448. Eds. B. W. O'Malley and A. R. Means. Plenum Press, New York.

Means, A.R. \& Huckins, C. (1974) Coupled events in the early biochemical actions of FSH on the Sertolc ells of the testis. In Hormone Binding and Activation in the Testis, pp. 145-165. Eds. A. R. Means and M. L. Dufau. Plenum Press, New York. 
McLean, W.S., Smith, A.A., Hansson, V., Nayfeh, S.N. \& French, F.S. (1974) Androgen receptor in seminiferous tubules of immature rat testis: absence of the receptor in the androgen insensitive Stanley-Gumbreck (Tfm) rat. Endocrinology 94, A-198.

McLean, W.S., Smtth, A.A., Hansson, V., Nayfeh, S.N. \& French, F.S. (1975) Characterization of the androgen receptor in rat testis. Endocrinology (in press).

Petrusz, P., Robyn, C. \& Diczfalusy, E. (1970) Biological effects of human urinary follicle stimulating hormone. Acta endocr., Copenh. 63, 454-475.

Ritzén, E.M., Dobbins, M.C., French, F.S. \& NaYfeh, S.N. (1972a) A high-affinity androgen binding protein in rat testis: evidence for its secretion in seminiferous fluid and passage through epididymis. Excerpta Med Int. Congr. Ser. No. 256, 79.

Ritzén, E.M., NAYfeh, S.N., French, F.S. \& Aronin, P.A. (1972b) Deficient nuclear uptake of testosterone in the androgen-insensitive (Stanley-Gumbreck) pseudohermaphrodite male rat. Endocrinology 91, 116-124.

Ritzén, E.M., Dobbins, M.C., Tindall, D.J., French, F.S. \& NAYfeh, S.N. (1973) Characterization of an androgen binding protein (ABP) in rat testis and epididymis. Steroids 21, 593-607.

Ritzén, E.M., French, F.S., Weddington, S.C., NAYFeH, S.N. \& Hansson, V. (1974a) Steroid binding in polyacrylamide gels. Quantitation at steady state conditions. F. biol. Chem. 249, 6597-6604.

Ritzén, E.M., Hagenäs, L., HANSSON, V., French, F.S. \& NAYFeH, S.N. (1974b) Androgen binding proteins in different testis compartments. F. Steroid Biochem. 5, 849-853.

Sanborn, B.M., Elkington, J.S.H. \& Steinberger, E. (1974) Hormonal influences on the testicular level of androgen binding protein. Endocrinology 94, A-199.

Smith, A.A., McLean, W.S., Hansson, V., Nayfeh, S.N. \& French, F.S. (1975) Androgen receptor in nuclei of rat seminiferous tubules. Steroids (in press).

Tindall, D.J., FRENCH, F.S. \& NAYFEH, S.N. (1972) Androgen uptake and binding in rat epididymal nuclei in vivo. Biochem. biophys. Res. Commun. 49, 1391-1397.

Tindal.t, D.J., Hansson, V., Sar, M., Stumpf, W.E., French, F.S. \& Nayfer, S.N. (1974) Further studies on the accumulation and binding of androgen in rat epididymis. Endocrinology 95, 1119 1128.

UhNJEM, O. \& TVETER, K.J. (1969) Localization of an androgen binding substance from the rat ventral prostate. Acta endocr., Copenh. 60, 571-578.

Vernon, R.G., Dorrington, J.H. \& Fritz, I.B. (1972) Testosterone binding by rat testicular seminiferous tubules. Excerpta Med. Int. Congr. Ser. No. 256, 79-80.

Vernon, R.G., Kopec, B. \& Fritz, I.B. (1973) Studies on the distribution of the high affinity testosterone binding protein (TBP) in rat testis seminiferous tubules. F. Endocr. 57, ii, Abstr.

Vernon, R.G., Kopec, B. \& Fritz, I.B. (1974) Observations on the binding of androgens by rat testis seminiferous tubules and testis extracts. Molec. cell. Endocr. 1, 167-187.

Woods, M.C. \& Simpson, M.E. (1961) Pituitary control of the testis of the hypophysectomized rat. Endocrinology 69, 91-125. 